\title{
Removal and extraction efficiency of Quaternary ammonium herbicides paraquat (PQ) from aqueous solution by ketoenol- pyrazole receptor functionalized silica hybrid adsorbent (SiNPz)
}

\author{
Shehdeh Jodeh ${ }^{1 *} \mathbb{B}$, Ghadir Hanbali ${ }^{1}$, Said Tighadouini ${ }^{2}$, Smaail Radi $^{2,3}$, Othman Hamed ${ }^{1}$ and Diana Jodeh ${ }^{4}$
}

\begin{abstract}
Pesticides and herbicides have been used extensively in agricultural practices to control pests and increase crop yields. Paraquat ( $\mathrm{PQT}^{2+}, 1,1$-dimethyl-4,4-dipyridinium chloride) is one of the herbicide that belois classified as bipyridines and is used over the world. The objective of this study is to use ketoenol-pyrazole receptor functionalized silica hybrid as adsorbent for removal $\mathrm{PQT}^{2+}$ from aqueous solution. The adsorbent was synthesized, and characterized using scanning electron microscopy (SEM), nuclear magnetic resonance (NMR), Thermal analysis and other techniques. Different experimental parameters such as the effect of the amount of adsorbent, solution $\mathrm{pH}$ and temperatures and contact times were studied. Pseudo-order kinetics models were studied, and our data followed a pseudo second order. Experimental data were analyzed for both Langmuir and Freundlich models and the data fitted well with the Langmuir isotherm model. To understand the mechanism of adsorption, thermodynamic parameters like standard enthalpy, standard Gibbs free energy, and standard entropy were studied. The study indicated that the process is spontaneous, exothermic in nature and follow physisorption mechanisms. The novelty of this study showed surface of pyrazol-enol-imine-substituted silica (SiNPz) has the ability to highlight the surface designed for efficient removal of $\mathrm{PQT}^{2+}$, from aqueous solutions more than other studies. The study also showed that ketoenol-pyrazole receptor can be regenerated in five cycles using $\mathrm{HNO}_{3}$ without affecting its adsorption capacity.
\end{abstract}

Keywords: Ketoenol-pyrazole receptor, Adsorption, Paraquat, Kinetics, Isotherm

\section{Introduction}

Pesticides have been used in agriculture to overcome pests and increase crop yields. They are used to reduce weeds, insecticides and fungicides. The amount of these pesticides that needed are not well known and most of the farmers exceeded the required quantity [1]. Most industries and food processing companies are always releasing some pesticides through their effluents [2]. Pesticides are organic compounds and they affect the

*Correspondence: sjodeh@hotmail.com

${ }^{1}$ Department of Chemistry, An-Najah National University, P. O. Box 7, Nablus, Palestine

Full list of author information is available at the end of the article environment in different ways. There are different types of pesticides categories including organophosphates, carbamates, substituted urea compounds, organochlorines, and pyrethroids. Due to their dangerous effect and toxicity in the environment, different research areas are involved to get rid of them from the environment [3].

Lately, agricultural types in Palestine are aiming to avoid low plant development and increase the production and the quality of the products. These changes help to introduce higher levels of herbicides in the agricultural ecosystem [4]. The main output of these agricultural practices is the contamination of soils and waters, which leads to degrade the soil-water-plant system and bioaccumulate herbicide residues. 
Paraquat $\quad \mathrm{PQT}^{2+}$, 1,1-dimethyl-4,4-dipyridinium chloride) is a herbicide and belongs to the class of the bipyridines. It is one of the most widely used herbicides in the world and forbidden in some countries. The advantages of paraquat over other herbicides is very quick and non-selective action to kill green plant tissue upon usage [5].

In the last years, several studies have been given to $\mathrm{PQT}^{2+}$, mainly due to the high rate of poisoning and fatalities attributed to it [4].

Several studies have been carried out for the removal of $\mathrm{PQT}^{2+}$ from aqueous medium and wastewater. One of them is related to the oxidation of $\mathrm{PQT}^{2+}$, which emphasize the destruction of the structure of the pesticide [5]. In this study, several reagents can be used for this study and can be enhanced by applying ultraviolet radiation, which increases the formation of free radicals. Some disadvantages of this experiment are the production of toxic substances if the degradation process was not carried right [6-8].

Another method of removal of $\mathrm{PQT}^{2+}$ is adsorption on solid adsorbents using different substrates and nanomaterials. Various adsorbents such as activated carbon [9], biological tissues [10] and modified materials [11] have been employed for the adsorption of $\mathrm{PQT}^{2+}$ from aqueous solutions. In previous studies, sawdust and peanut shell powder were explored as adsorbents for the removal of phosphorus and other dyes from aqueous solutions [12-16].

Pesticides and herbicides are determined using instrumentation such as gas chromatography (GC) and highperformance liquid chromatography (HPLC) [17]. Their degradation is involved by crops through their metabolites [18]. There are several methods that are used for determination of pesticides like nanotechnology-based protocols were used to investigate these problems [19]. Some examples like, some metals and silica nanoparticles are used for such studies [19]. In this study, the ability of pyrazole and its derivatives to play as ligands with $\mathrm{sp}^{2}$ hybrid nitrogen donors have been the study areas of several scientists. This is shown in different research and published papers in this field [20,21]. Besides that, ketoenol moiety has an important type of ligand in view of its distinct structural characteristics and high synthetic utility [17]. Research on $\beta$-ketoenol derivatives and their metal complexes have been studied by a number of phenomena's such as their important practical application.

This kind of molecules have two possibilities of coordination sites and can act as a uni- or bidentate ligand or coordinate to the metal atom through monoionic or neutral form. Sometimes they form a bridge between two metal atoms. It is obvious that will lead for the possibility to opens this kind of ligand to be grafted onto silica gel and increase adsorption capacity toward heavy metals or other contaminates of interest.

The goal of this study is to report the investigation of the fabrication of highly branched adsorbent and chelated material using covalent immobilization of a prepared mixed ligand ( $\beta$-ketoenol-pyrazole) onto silica particles to study the adsorption of $\mathrm{PQT}^{2+}$ from aqueous solutions.

\section{Experimental}

\section{Materials and methods}

The solvents and chemicals used in this study were purchased from Aldrich, USA. All of them with high purity. Silica gel (E. Merch) with a particle size in the range of 70-230 mesh, median pore diameter $60 \AA$, was activated using heat at $160-170{ }^{\circ} \mathrm{C}$ within $24 \mathrm{~h}$. The salivating agent 3-aminopropyltrimethoxysilane (Janssen Chimica) was very pure. All the characterization of the samples was described and reported in our previous study for the removal of heavy metals [17]. Paraquat dichloride was purchased from (Fluka, Steinheim, Germany).

\section{Synthesis of (2Z)-1-(1,5-dimethyl-1H-pyrazole-3-yl)-3- hydroxybut-2-en-1-one}

As we reported in previous study [22], amount of ethyl 1,5-dimethyl- $1 H$-pyrazole-3-carboxylate $(30 \mathrm{mmol})$ dissolved in $30 \mathrm{~mL}$ of toluene and added to a suspension of sodium $(52.5 \mathrm{mmol})$ in $50 \mathrm{~mL}$ of anhydrous toluene. Acetone (2.5 g; $42.5 \mathrm{mmol}$ ) dissolved in $10 \mathrm{~mL}$ of toluene was added at very low temperature. The final solution was shacked vigorously at room temperature for $48 \mathrm{~h}$.

The precipitate was filtered and washed several times with toluene and then dissolved in water. The final $\mathrm{pH}$ was close to 5 . The solution was extracted with $\mathrm{CH}_{2} \mathrm{Cl}_{2}$ and the bottom layer (organic) was dried using anhydrous sodium sulfate and all solvents were evaporated to have very concentrated sample using vacuum. The compound (2Z)-1-(1,5-dimethyl-1H-pyrazol-3-yl)-3hydroxybut-2-en-1-one (Scheme 1) was obtained from the residue which was chromatographed on silica using $\mathrm{CH}_{2} \mathrm{Cl}_{2}$ as eluant. The final product was characterized by $\mathrm{X}$-ray crystallography and NMR as described in our previous study $[22,23]$.

\section{Synthesis of 3-aminopropylsilica (SiNH2)}

To accomplish this synthesis, reaction between the silylating agent and silanol groups on the silica surface was occured. An amount of activated silica gel $\mathrm{SiO}_{2}(30 \mathrm{~g})$ mixed with about $150 \mathrm{~mL}$ of dried toluene was refluxed and stirred under nitrogen atmosphere for about $2 \mathrm{~h}$. After that, $10 \mathrm{~mL}$ of aminopropyltrimethoxysilane was added dropwise to the suspended solution and the final mixture was refluxed for 2 days. The precipitate was 


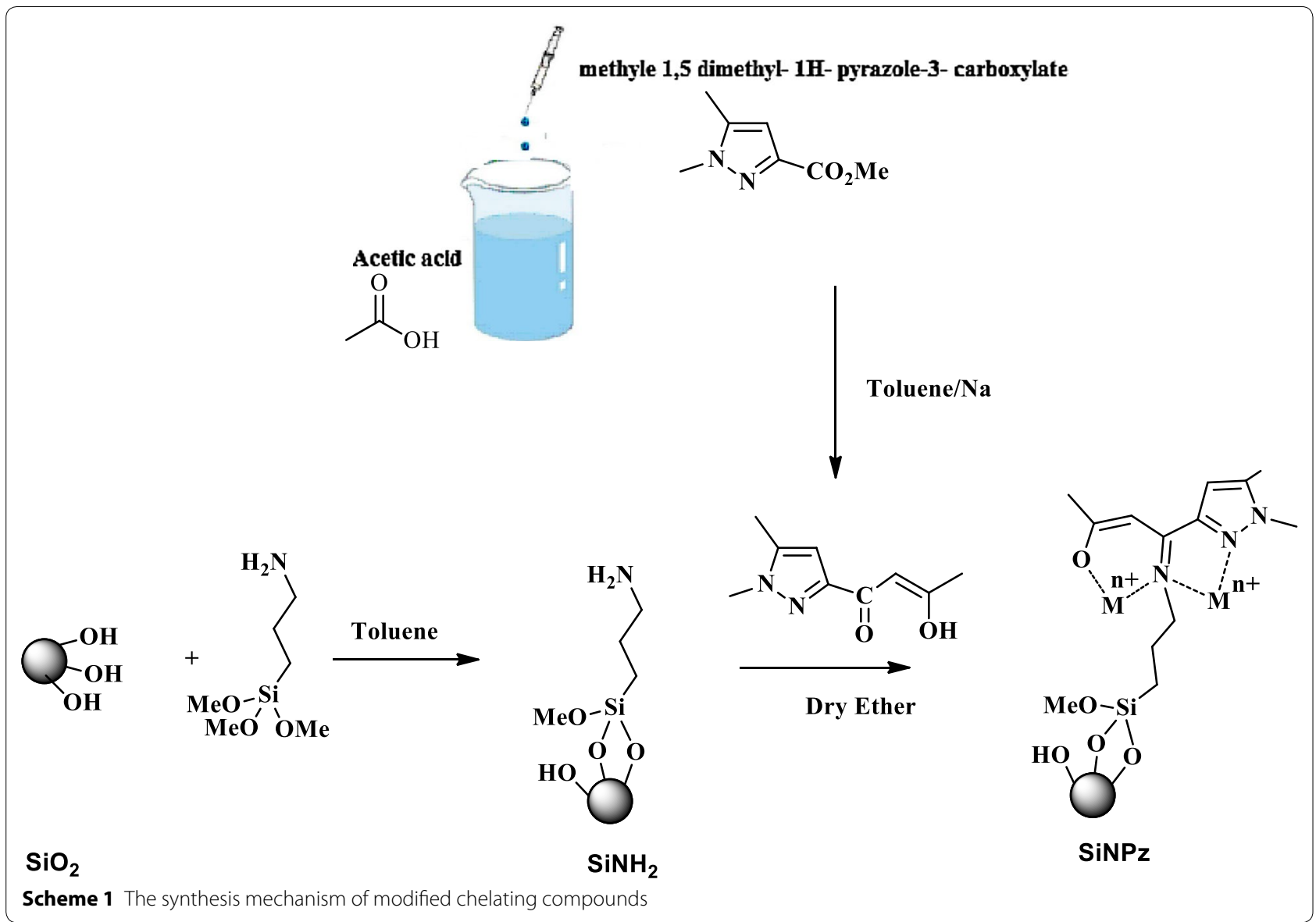

filtered and washed several times with both toluene and ethanol. The solution was extracted using a mixture of ethanol and dichloromethane (1:1) for about $12 \mathrm{~h}$ to separate all residues (Scheme 1). In this stage we named the immobilized silica gel $\mathrm{SiNH} 2$ which was dried at room temperature [22].

\section{Synthesis of pyrazol-enol-imine-substituted silica (SiNPz)}

To prepare and synthesizedf SiNPz, amount of 3-aminopropylsilica (SiNH2) (5 g) and (2Z)-1-(1,5-dimethyl$1 H$-pyrazol-3-yl)-3-hydroxybut-2-en-1-one (3 g) were dissolved in $60 \mathrm{~mL}$ of dry diethyl ether. The mixture was stirred mechanically for $24 \mathrm{~h}$ at room temperature. As mentioned before, the solution was filtered and Soxhlet extracted using acetonitrile, methanol and dichloromethane for $12 \mathrm{~h}$, respectively. Final product was dried at $70{ }^{\circ} \mathrm{C}$ for $24 \mathrm{~h}$.

\section{Sample characterization \\ Elemental analysis}

The elemental analysis for the synthesis of SiNH2 showed $4.46 \%$ of carbon and $1.66 \%$ of nitrogen. While the synthesis of $\mathrm{SiNPz}$ showed $9.73 \%$ of carbon and $2.8 \%$ of nitrogen. The variation of carbon and nitrogen between the two samples indicating the variation of organic moieties. The increase of both nitrogen and carbon in the second sample (SiNPz) indicated that the (2Z)-1-(1,5dimethyl-1H-pyrazol-3-yl)-3-hydroxybut-2-en-1-one was attached to $\mathrm{SiNH} 2$.

\section{Surface properties}

All NMR, FT-IR, SEM, surface pore volume and thermal analysis were done for the sample prepared with $\mathrm{SiNH} 2$ and $\mathrm{SiNPz}$ and the sample was used for the application of studying the efficiency of removing heavy metals from aqueous solution [22].

\section{Measurements of $P Q$ in water}

In our study for determination PQ in solution, a sensitive method was used and reported by Rai et al. [23, 24]. Where sodium borohydride is used as reducing reagent for the reduction of PQ to form a stable blue colored free radical ion. The advantages of the method are simple, reproducible, nontoxic reducing agent and excellent stability of the blue free radical ion. 
In summary, $1000 \mathrm{mg} \mathrm{L}^{-1}$-aqueous solution of paraquat (PQT) was prepared by dissolving $69.1 \mathrm{mg}$ of paraquat dichloride (Aldrich, USA) in deionized water to make $50 \mathrm{~mL}$ of solution in a volumetric flask. Different working standard solutions and calibration curves were prepared by appropriate dilution from the stock solution depending on the experiment.

The absorption spectra of the blue colored solution showed maximum absorbance at $600 \mathrm{~nm}$ while the reagent blank had a negligible absorbance at this wavelength.

The reproducibility of the method was studied by replicate analysis of $3.0 \mu \mathrm{g}$ of PQ in $10 \mathrm{~mL}$ solution for 5 days. The SD and relative SD of absorbance values were found to be \pm 0.0053 and $1.47 \%$ respectively.

\section{Adsorption kinetics}

The adsorption kinetics experiments were studied as follow: $(50 \mathrm{mg} / \mathrm{L}, 100 \mathrm{mg}$ adsorbant and agitation speed of $300 \mathrm{rpm})$. The studies on the adsorption using the SiNPz adsorbent have indicated that the adsorption showed very fast and increased slowly after $50 \mathrm{~min}$ up $200 \mathrm{~min}$. The samples were drawn from the beaker by a pipet of $10 \mathrm{~mL}$ at different interval times of $1,5,10,30,60,90$, and $180 \mathrm{~min}$. Each sample was filtered with filter paper of $45 \mu \mathrm{m}$ and analyzed using the spectrophotometer (Hitachi UV-1500A) at $600 \mathrm{~nm}$. Both the effect of temperatures $\left(15,25,35\right.$ and $\left.45^{\circ} \mathrm{C}\right)$ and the $\mathrm{pH} 2,4,6,10$ and 12) were studied. Each time we study one parameter we keep the other constant. This experiment was done with repletion of 3 times and the average was used when we analyzed the data.

\section{Adsorption isotherm}

In each experiment, about $100 \mathrm{mg}$ of $\mathrm{SiNPz}$ adsorbent was placed into a shaker bath at $25 \pm 0.1{ }^{\circ} \mathrm{C}$ and initial $\mathrm{pH}$ of 11.0 for all experiments. Isotherm experiments were handled by shaking (at $300 \mathrm{rpm}$ ) with a known volume $(50 \mathrm{~mL})$ of paraquat solutions at different initial concentration and specified contact time. The concentration of paraquat was analyzed at the end of each contact period and the measurements were repeated 3 times.

\section{Results and discussion}

The parameters affecting the adsorption of paraquat, such as dosage, initial concentration, $\mathrm{pH}$, and temperature, were studied. In our study, for those parameters, we kept all variables constant except the one we want to study.

\section{Investigation of adsorption parameters $\mathrm{pH}$ effect on $\mathrm{PQT}^{2+}$ adsorption}

The amount of paraquat adsorption increases with $\mathrm{pH}$ (Fig. 1). As usual, dsorption depends on the type and

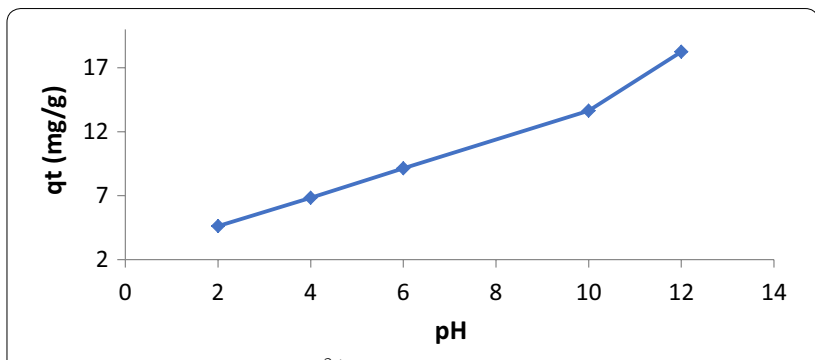

Fig. 1 Effect of $\mathrm{pH}$ on $\mathrm{PQT}^{2+}$ removal

morphology of the adsorbent surface. By decreasing $\mathrm{pH}$, the $\mathrm{H}^{+}$usually competes with adsorbate at different exchange sites in the system.

From (Fig. 1), the amount of adsorption was very small at $\mathrm{pH}=2$ and increased when the solution become basic (as $\mathrm{pH}$ increases).

The small amount of adsorption at low $\mathrm{pH}(<2)$ was due to the high mobility of $\mathrm{H}^{+}$and adsorbed over PQT ${ }^{2+}$ and this lead to the increased of the adsorbed amount of cationic paraquat which was increased in response to the increasing number of negatively charged sites that exist due to the loss of $\mathrm{H}^{+}$from the surface [25].

\section{Temperature effect on $\mathrm{PQT}^{2+}$ adsorption}

The effect of temperature on the adsorption equilibrium is shown in Fig. 2. From which it can be seen that the adsorption capacity was favored by increasing temperature. The capacity towards the adsorption of $\mathrm{PQT}^{2+}$ increased 1.2-times when the temperature was increased from 15 to $45^{\circ} \mathrm{C}$ and the temperatures chosen is very close to that find in drinking water $[26,27]$. This was proven in our results when we studied the thermodynamics parameters and it was endothermic. This suggest that adsorbate has very high affinity for this pesticide and there is no competition for the solvent which leads to formation of monolayer of $\mathrm{PQT}^{2+}$ covering the adsorbate surface.

\section{Concentrations effects on $\mathrm{PQT}^{2+}$ adsorption}

Effect of initial concentration of $\mathrm{PQT}^{2+}$ adsorption processes was studied with fixing previous conditions. The results are shown in Fig. 3. The figure shows the effect of contact time on the removal of paraquat by $\mathrm{SiNPz}$ as a function of the amount removed (qt). The figure showed that the amount removed for paraquat pollutants increased during the first $15 \mathrm{~min}$ and reached equilibrium after that. When concentration increases from 5 to $50 \mathrm{mg} / \mathrm{L}$, the adsorption capacity is also increasing. This may be because of a gradual increase in the electrostatic attraction between $\mathrm{PQT}^{2+}$ and the absorbent desired active sites [28]. 


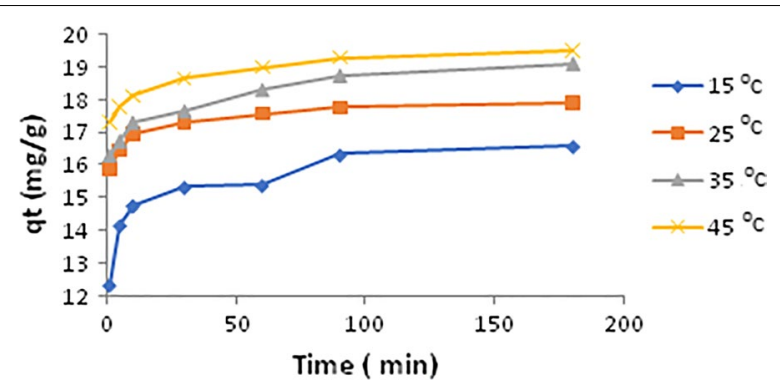

Fig. 2 Effect of temperature on $\mathrm{PQT}^{2+}$ removal by SiNPz

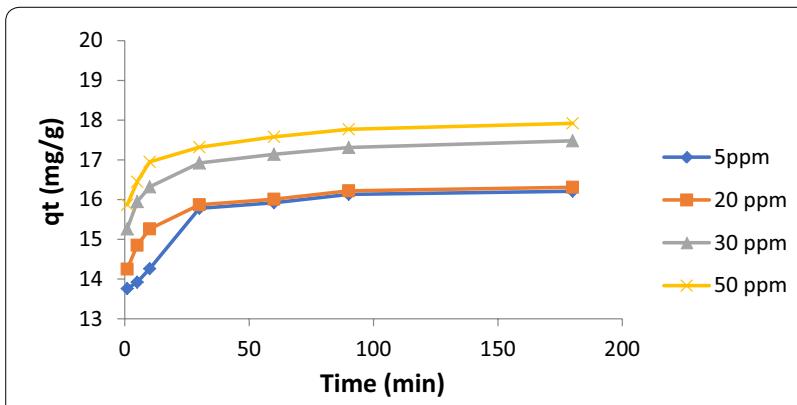

Fig. 3 Effect of concentration on $\mathrm{PQT}^{2+}$ removal by SiNPz

\section{Adsorption isotherm}

To understand the adsorption capacity, we have to design an experiment at a specific temperature to remove paraquat from the aqueous solution.

There are several isotherm models like Langmuir, Freundlich, BET, etc. which can be applied at all temperatures. All of these models have equations that can be used, and the data will be fit into these equations. One of the factors that can lead to the type of isotherm model is the correlation coefficients, $\mathrm{R}^{2}$ [28].

The Langmuir equation is one of the most used and can be expressed as [29]:

$$
\frac{C_{e}}{q_{e}}=\frac{1}{b Q_{o}}+\frac{1}{Q_{o}} C_{e}
$$

where Ce represents the equilibrium concentration of the adsorbate $(\mathrm{mg} / \mathrm{L})$; b is usually, the Langmuir affinity constant $(\mathrm{L} / \mathrm{mg}) . \mathrm{Q}_{0}$ is the adsorption capacity at equilibrium $(\mathrm{mg} / \mathrm{g})$; and $\mathrm{q}_{\mathrm{e}}$ is the amount of adsorbate per unit mass of adsorbent $(\mathrm{mg} / \mathrm{g})$.

The other type of isotherm model is Freundlich isotherm is an empirical formula which used for low concentrations and can be presented as [30]:

$$
\log q_{e}=\log K_{F}+\frac{1}{n} \log C_{e}
$$

where $K_{F}$ is the Freundlich constant that deal with adsorption capacity $(\mathrm{mg} / \mathrm{g}$ ) and $\mathrm{n}$ is the heterogeneity coefficient which leads to how favorable the adsorption process $(\mathrm{g} / \mathrm{L})$.

In the above equation the slope $1 / \mathrm{n}$, having the value between 0 and 1 , which describe adsorption intensity and surface heterogeneity, If the value of $1 / \mathrm{n}$ is close to zero, this means more heterogeneous [31], and if the value of $1 / \mathrm{n}$ less than one this indicates Langmuir-type isotherm and at the same time becomes difficult to adsorb additional adsorbate molecules at higher adsorbate concentrations [32]. Table 1 and Figs. 4 and 5 summarizes the whole data of Freundlich and Langmuir isotherms, indicating the satisfactorily good correlation between the model and the experimental data. The Langmuir isotherm shows very well fit to the data, with correlation coefficients $\left(\mathrm{R}^{2}\right)$ of 0.9986 compared with 0.7070 for Freundlich isotherm. A value for $1 / \mathrm{n}(0.0393)$ below one leads to a Langmuir-type isotherm. It is observed that the monolayer adsorption capacity (i.e., $\mathrm{q}_{\mathrm{m}}$ ) and Langmuir constant (i.e., $\mathrm{K}_{\mathrm{L}}$ ), are high enough and very closed to other previous studies [32]. This result is reasonable since the adsorption affinity and monolayer adsorption capacity will be enhanced by the increase in surface area observed for the adsorbent. Therefore, the monolayer adsorption capacities of adsorbents are mainly dependent upon physical properties such as Brunauer-EmmettTeller BET surface area.

\section{Adsorption kinetics}

Presenting the experimental data through kinetics equations like the Lagergren pseudo-first-order model, the pseudo-second-order model will describe the mechanism of adsorption and degradation of paraquat in aqueous solution. Such studies give information about the possible mechanism of adsorption of paraquat and different transition states on the final complex of paraquat and the adsorbent. From the reactions parameters like rate constants and adsorption capacity factors, one can have an idea about the adsorption dynamics and this will help the industry for other applications.

The adsorption experimental data of paraquat by the $\mathrm{SiNPz}$ were analyzed using the most common kinetic models to understand the nature of the adsorption process.

Table 1 Parameters in Langmuir and Freundlich adsorption isotherm models of paraquat onto ketoenolpyrazole at $298 \mathrm{~K}$

\begin{tabular}{llll}
\hline Langmuir isotherm parameters & $\mathrm{Q}_{0}(\mathrm{mg} / \mathrm{g})$ & $\mathrm{b}(\mathrm{L} / \mathrm{mg})$ & $\mathrm{R}^{2}$ \\
& 17.63 & 0.80 & 0.9986 \\
Freundlich isotherm parameters & $\mathrm{n}$ & $1 / \mathrm{n}$ & $\mathrm{R}^{2}$ \\
& 25.44 & 0.0393 & 0.707 \\
\hline
\end{tabular}




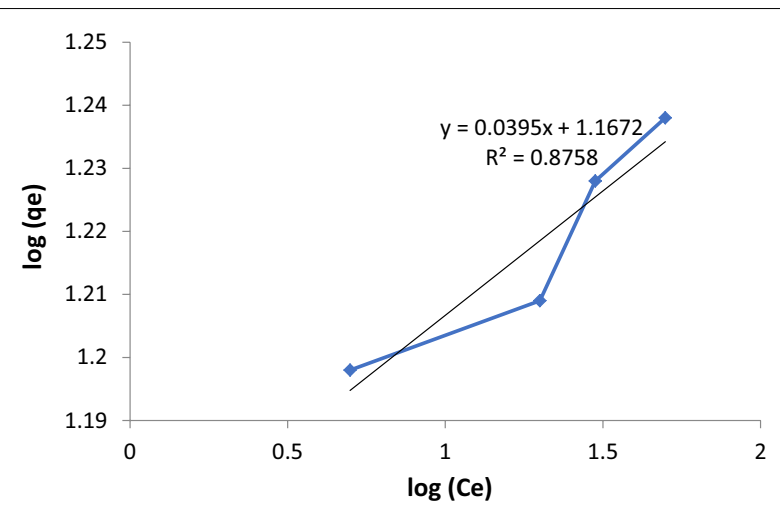

Fig. 4 Isothermal adsorption of paraquat in aqueous solution onto SiNPz at 298 K of Freundlich model

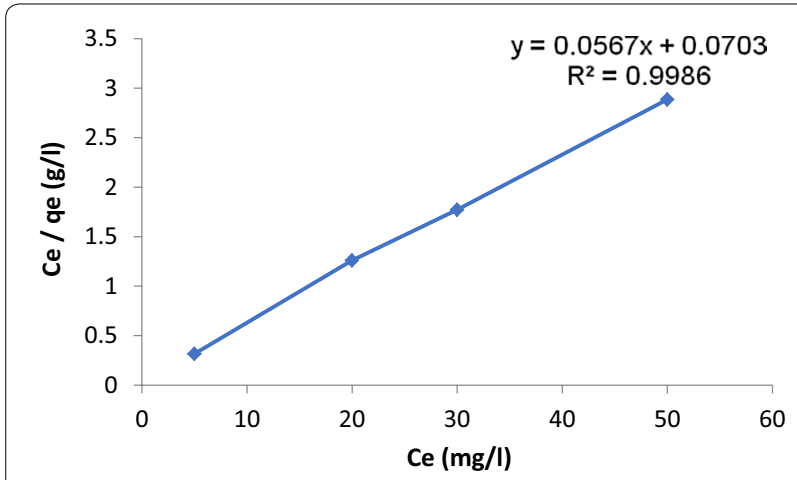

Fig. 5 Isothermal adsorption of paraquat in aqueous solution onto SiNPz at $298 \mathrm{~K}$ of Langmuir model

The adsorption of paraquat by solid adsorbents such as $\mathrm{SiNPz}$ was fitted to one of the most used kinetic models; Lagergren pseudo-first-order model [33], the equation can be written as the following:

$$
\log \left(q_{e}-q_{t}\right)=\log q_{e}-\frac{K_{1}}{2.303} t
$$

where $k_{1}\left(\min ^{-1}\right)$ is the pseudo-first-order adsorption rate coefficient, and $\mathrm{q}_{\mathrm{e}}$ and $\mathrm{q}_{\mathrm{t}}$ are the values of the amount adsorbed per unit mass at equilibrium at time $t$, respectively. Plotting $\ln \left(\mathrm{q}_{\mathrm{e}}-\mathrm{q}_{\mathrm{t}}\right)$ vs. $\mathrm{t}$ for paraquat did not give straight lines as it is clear from Fig. 6 with very low regression coefficients $(0.707)$ as shown in Table 2.

From Table 2, the calculated values of the amount adsorbed at equilibrium $\left(\mathrm{q}_{\mathrm{e}}\right.$, calc) were far from the experimental values $\left(\mathrm{q}_{\mathrm{e}}\right.$, exp) for the pseudo -first order which means that the adsorption cannot be represented by this model.

The pseudo-second-order equation was also used for describing the adsorption of the paraquat by $\mathrm{SiNPz}$ [34].

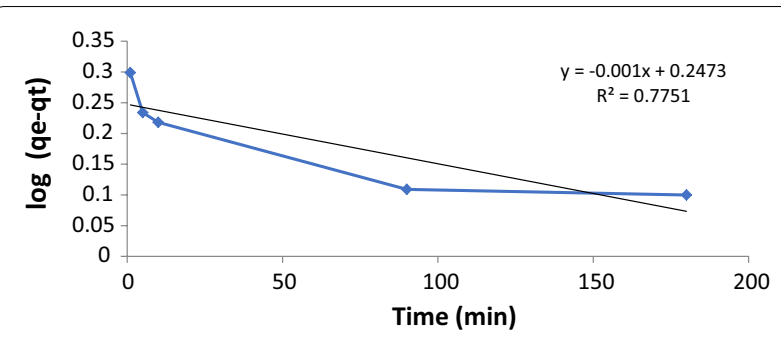

Fig. 6 Pseudo-first order plots for the adsorption of paraquat by SiNPz (experimental conditions: $10 \mathrm{~mL}$ sample volume, $100 \mathrm{mg} \mathrm{SiNPz}$, and paraquat concentration $20.0 \mathrm{mg} \mathrm{L}^{-1}$ )

The equation of the pseudo-second-order rate is given as:

$$
\mathrm{t} / \mathrm{q}_{\mathrm{t}}=1 / \mathrm{K}_{2}\left(\mathrm{q}_{\mathrm{e}}\right) 2+\mathrm{t} / \mathrm{q}_{\mathrm{e}}
$$

[Experimental conditions: $10 \mathrm{~mL}$ sample volume, $100 \mathrm{mg}$ ketoenol-pyrazole, and paraquat concentration $\left.20.0 \mathrm{mg} \mathrm{L}^{-1}\right)$, where $\mathrm{k}_{2}(\mathrm{~g} /(\mathrm{mg} \mathrm{min})]$ is the pseudo-second-order rate coefficient, and $\mathrm{q}_{\mathrm{e}}$ and $\mathrm{qt}$ are the values of the amount adsorbed per unit mass at equilibrium and at any time t, respectively. From Fig. 7 and Table 2, the pseudo-second-order rate equation to the adsorption of the paraquat by SiNPz showed good converging for the experimental data, and excellent regression coefficients $\left(\mathrm{R}^{2}=0.9897\right)$

In case of pseudo-second order, it is clear from Table 2, that both the correlation coefficient $\mathrm{R}^{2}$ which is very close to one and the values for both $\left(\mathrm{q}_{\mathrm{e}}\right.$ Calc) and $\left(\mathrm{q}_{\mathrm{e}}\right.$ Exp) were very close and this indicates that the adsorption followed pseudo -second order.

\section{Adsorption rate-controlling mechanism}

The sorption of paraquat by $\mathrm{SiNPz}$ is a very complex process where both characteristics of both (adsorbate and adsorbent) plays an important role. Different factors will be involved in this process: bulk solution will be involved when adsorbate diffused from the solution to the boundary surface of the solution surrounding SiNPz. Other phenomena are film diffusion when paraquat diffuse through the film surrounding SiNPz. Finally, what we called pore diffusion when paraquat finds pores inside SiNPz. Usually, the slowest one will control the adsorption.

Webber and Morris developed an equation describing the intraparticle diffusion and can be written as the following equation [35].

$$
\mathrm{q}_{\mathrm{t}}=\mathrm{K}_{\mathrm{id}} \mathrm{t}^{1 / 2}+\mathrm{C}
$$

where $\mathrm{q}_{\mathrm{t}}\left(\mathrm{mg} \mathrm{g}^{-1}\right)$ is adsorption capacity at any time $(\mathrm{t}), \mathrm{k}_{\text {id }}\left(\mathrm{mg} \mathrm{g}^{-1} \mathrm{~min}^{1 / 2}\right)$ is the intra-particle diffusion rate constant, and $\mathrm{C}\left(\mathrm{mg}^{\mathrm{g}-1}\right)$ is a constant proportional to 
Table 2 Pseudo first order and pseudo second order kinetic model parameters for $\mathrm{PQT}^{2+}$ adsorption by SiNPz

\begin{tabular}{llllll}
\hline Pseudo first order & $\mathrm{q}_{\mathrm{e}}$ (exp) 17.32 & $\mathrm{k}_{1}$ & $\mathrm{q}_{\mathrm{e}}$ (cal) & $\mathrm{R}^{2}$ & $\mathrm{~K}_{\text {id }}$ \\
& & 0.002 & 0.753 & 0.7751 & 0.156 \\
Pseudo second order & & $\mathrm{k}_{2}$ & $\mathrm{q}_{\mathrm{e}}$ (cal) & $\mathrm{R}^{2}$ & $\mathrm{C}$ \\
& & 0.096 & 17.95 & 0.9897 & 16.153
\end{tabular}

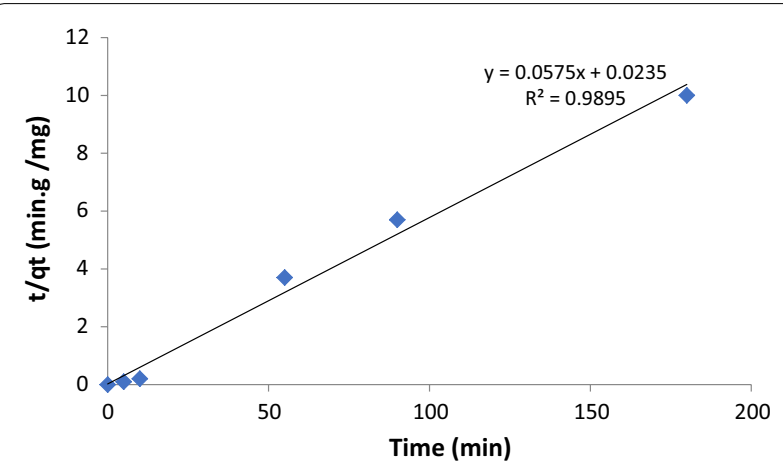

Fig. 7 Pseudo-second-order plots for the adsorption of paraquat by SiNPz

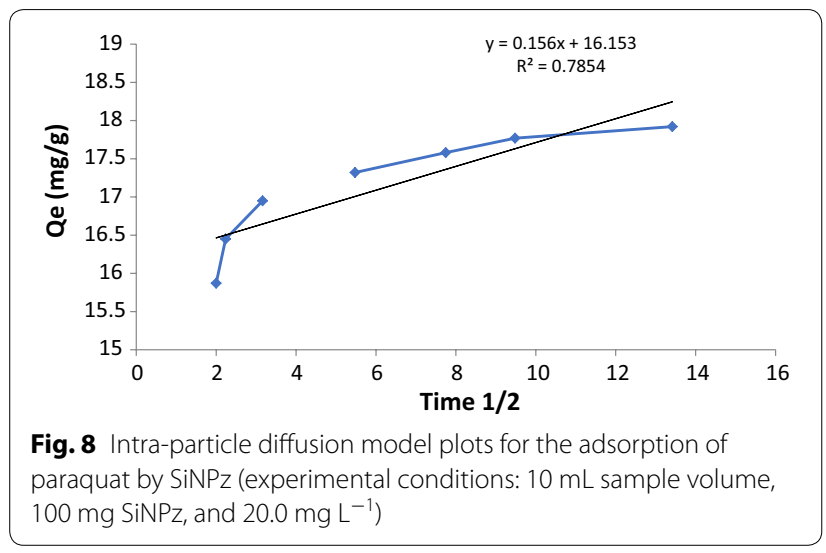

the thickness of the boundary layer. Usually, the larger value of $\mathrm{C}$, the better and greater boundary layer thickness. Plotting data of $\mathrm{q}_{\mathrm{t}}$ against $\mathrm{t}^{1 / 2}$ usually describe the process of diffusion controlled. From the plot, if there are multiple linear plots, means the adsorption of paraquat by $\mathrm{SiNPz}$ is controlled by more than one step. Figure 8 , represent the experimental data paraquat adsorption by SiNPz using Webber-Morris model and the data showed two straight lines. Usually, the first portion of the straight line represents the diffusion process which is controlled by the external surface of the adsorbent, while the second one represents the intraparticle diffusion. The intercepts of the straight lines usually, gives the boundary layer thickness. In our study, we have two steps which means

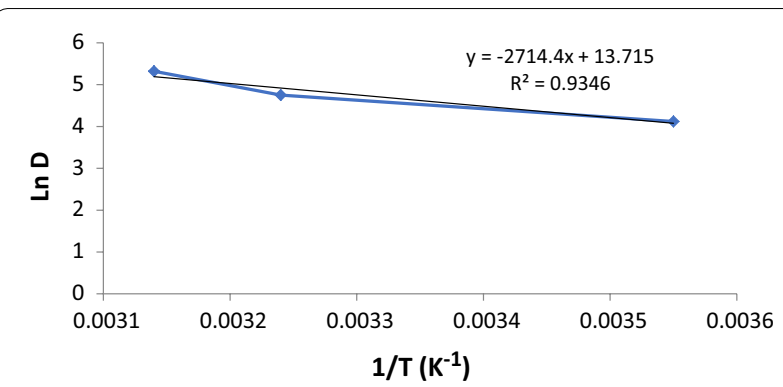

Fig. 9 A plot of In D vs. 1/T for the calculations of thermodynamic parameters for the adsorption of paraquat by SiNPz (experimental conditions: $50 \mathrm{~mL}$ sample volume, $50 \mathrm{mg} \mathrm{SiNPz}$, and concentration $20.0 \mathrm{mg} \mathrm{L}^{-1}$ )

that the diffusion was controlled by the external surfaces and intraparticle diffusion. Another thing, the data did not pass through origin indicating a difference in diffusion rates between the two steps as shown in Table 2 .

\section{Thermodynamic studies}

In this study, different parameters were calculated like the standard free energy, standard enthalpy, and standard entropy. The aim of this study is to understand spontaneity and to understand the nature of adsorption. The following equation was used [36]:

$$
\mathrm{D}=\mathrm{q}_{\mathrm{e}} / \mathrm{C}_{\mathrm{e}}
$$

where $\mathrm{q}_{\mathrm{e}}$ is the amount of paraquat adsorbed by $\mathrm{SiNPz}$, $(\mathrm{mg} / \mathrm{g})$ at equilibrium, and $\mathrm{C}_{\mathrm{e}}$ is the equilibrium concentration of paraquat in the solution $(\mathrm{mg} / \mathrm{L})$. The $\Delta \mathrm{H}$ and $\Delta \mathrm{S}$ can be calculated from the following equation [37]:

$$
\operatorname{Ln} \mathrm{D}=\Delta \mathrm{S} / \mathrm{R}-\Delta \mathrm{H} / \mathrm{RT} \text {. }
$$

Plotting $\ln \mathrm{D}$ vs. $1 / \mathrm{T}$ for the adsorption of paraquat, a straight line was obtained and shown in Fig. 9 and Table 3.

The standard free energy $\Delta G^{\circ}$ can be calculated using this equation:

$$
\Delta \mathrm{G}^{\circ}=\Delta \mathrm{H}^{\circ}-\mathrm{T} \Delta \mathrm{S}^{\circ} .
$$

From Fig. 9, both $\Delta \mathrm{H}$ and $\Delta \mathrm{S}$ can be calculated from the slope and the intercept of the straight line. The $\Delta \mathrm{H}$ values was $+22.56 \mathrm{~kJ} / \mathrm{mol}$, for the adsorption of paraquat by $\mathrm{SiNPz}$ from the aqueous solution. This positive value indicates the endothermic nature of the adsorption of paraquat by $\mathrm{SiNPz}$, which confirmed our previous study of the effect of temperature that adsorption increased when temperature increased. Also, the value of $\Delta \mathrm{H}$ suggests a strong affinity between paraquat by $\mathrm{SiNPz}$ and the physical nature of the adsorption. The low value of $\Delta \mathrm{S}, 0.114 \mathrm{~J} / \mathrm{mol} \mathrm{K}$, suggested very low of randomness at 
Table 3 The values of the calculated thermodynamic parameters of $\mathrm{PQT}^{2+}$ adsorption

\begin{tabular}{llllll}
\hline$\Delta \mathbf{S}^{\circ}(\mathrm{J} / \mathrm{mol} \mathrm{k})$ & $\Delta \mathrm{H}^{\circ}(\mathrm{kJ} / \mathrm{mol})$ & \multicolumn{4}{l}{$\Delta \mathrm{G}^{\circ}(\mathrm{kJ} / \mathrm{mol})$} \\
\cline { 3 - 6 } & & $\mathbf{2 8 8 \mathrm { K }}$ & $\mathbf{2 9 8} \mathrm{K}$ & $\mathbf{3 0 8 K}$ & $\mathbf{3 1 8 K}$ \\
\hline 0.114 & 22.56 & -10.27 & -11.41 & -12.55 & -13.69 \\
\hline
\end{tabular}

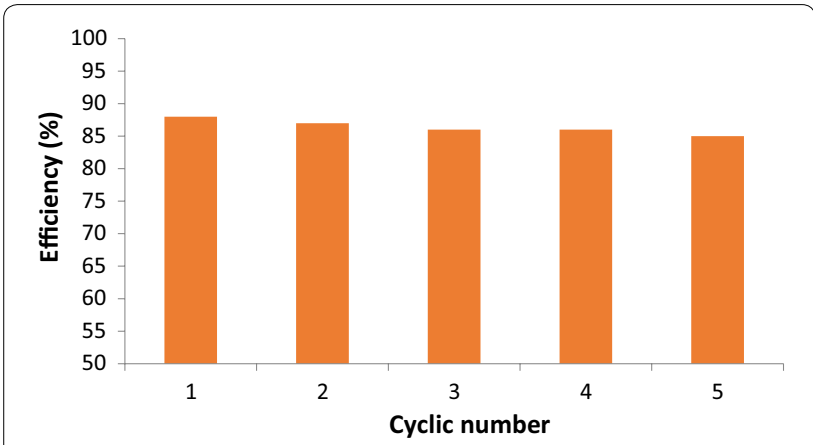

Fig. 10 Adsorption-desorption experiments of paraquat by SiNPz

the SiNPz/solution interface during the adsorption and immobilization of paraquat.

The $\Delta \mathrm{G}$ values were negative which indicates that the adsorption of paraquat by SiNPz was favored and spontaneous. The negative values of $\Delta \mathrm{G}$, and positive values of $\Delta \mathrm{H}$, and $\Delta \mathrm{S}$ suggested that the adsorption of paraquat process is an entropy-driven process.

\section{Regeneration of adsorbent}

In order to make the adsorption more environmentally friendly, regeneration experiment was studied. Regeneration is an important factor to determine the cost-effectiveness and the possibility of reuse several times. The main important factor is the possibility to reuse paraquat that has been adsorbed for other things.

Thermodynamics study showed that the adsorption process is governed by physisorption, indicating a week force between adsorbent and adsorbate. This means that the regeneration process is feasible. Also, from the study of $\mathrm{pH}$ effect on adsorption, the removal efficiency increased as $\mathrm{pH}$ increased. In this case, decreasing $\mathrm{pH}$ will enhance the desorption process. This suggests that washing the contaminated ketoenol pyrazole with an acid like $\mathrm{HNO}_{3}$ is more efficient than with basic solution.

Figure 10 shows the cycles of adsorption-desorption experiments using $6 \mathrm{mM} \mathrm{HNO}_{3}$ and reused for 5 successive removal processes with efficiency higher than $87 \%$. This reasonable result is due to the fact that entropy is usually occurring from the bulk solution like adsorbent's pores to more dilute $\mathrm{HNO}_{3}$ solution. This means that adsorption of paraquat is reversible, and bonding between active sites is not strong.

\section{Conclusion}

Pesticides have been used extensively in agriculture to control pests and increase crop yields. They are used to control weeds, insecticides and fungicides. This study approved that $\mathrm{SiNPz}$ receptor could be used as an adsorbent for paraquat from aqueous solution in a short time with high removal efficiency. The optimization parameter for adsorption like, $\mathrm{pH}$, temperature, and dosage were studied and found to playan important role in the capacity of adsorption increased with increasing temperatures and $\mathrm{pH}$. The adsorption isotherm was studied, and the data were best fitted with the Langmuir model. The data were fitted to both pseudo-first order and pseudo-second order and the results fitted much better to pseudo-second order using both correlation coefficient $\mathrm{R}^{2}$ and $\mathrm{q}_{\mathrm{e}}$ experiment was very closed to the calculated one. Thermodynamics study showed that the adsorption is spontaneous and exothermic with physisorption nature of the adsorption process.

The regeneration studies confirmed that the adsorbent can be reused for several times with adsorption capacity of more than $87 \%$. This means that the adsorption process is efficient simple and cost-effective and can be used in large-scale industry.

\footnotetext{
Abbreviations

Paraquat: $\mathrm{PQT}^{2+}$, 1,1-dimethyl-4,4-dipyridinium chloride; SEM: scanning electron microscopy; NMR: nuclear magnetic resonance; SiNPz: pyrazol-enolimine-substituted silica; GC: gas chromatography; HPLC: high-performance liquid chromatography; SiNH2: 3-aminopropylsilica; $R^{2}$ : correlation coefficients; Ce: equilibrium concentration; b: Langmuir affinity constant; $Q_{0}$ : adsorption capacity at equilibrium (mg/g); $q_{e}$ : amount of adsorbate per unit mass of adsorbent $(\mathrm{mg} / \mathrm{g})$; $\mathrm{K}_{\mathrm{F}}$ : Freundlich constant; $\mathrm{n}$ : heterogeneity coefficient; $\mathrm{K}_{\mathrm{L}}$ : Langmuir constant; BET: Brunauer-Emmett-Teller; K2: pseudo-second-order rate coefficient, the amount adsorbed per unit mass at equilibrium and at any time $\mathrm{q}_{\mathrm{e}}$ and $\mathrm{q}_{\mathrm{i}}$ Kid: intra-particle diffusion rate constant; $\mathrm{C}\left(\mathrm{mg}^{\mathrm{g}-1}\right)$ : a constant proportional to the thickness of the boundary layer; $\Delta \mathrm{H}$ : Enthalpy; $\Delta \mathrm{S}$ : Entropy; $\Delta G^{\circ}$ : standard free energy; $R(8.314 \mathrm{~J} / \mathrm{K}$.mol): ideal gas constant.
}

\section{Acknowledgements}

The authors would like to thank the scientific research at An-Najah National University for their financial support under Project \# ANNU-1718-SC020. This funding helps in analysis the results outside and purchasing chemicals. They also, like to thank the department of chemistry at Mohammed Premier and An-Najah National Universities for their help and using the instrumentation over there.

\section{Authors' contributions}

SJ wrote the manuscript. GH did most of the adsorption experiment, ST and SR did the preparation and characterization of the adsorbent. OH and DJ helped in editing the English language beside adding some paragraphs to the text. All authors read and approved the final manuscript.

Funding

Not applicable. 


\section{Availability of data and materials}

The datasets used and/or analyzed during the current study are available from the corresponding author on reasonable request.

\section{Competing interests}

The authors declare that they have no competing interests.

\section{Author details}

1 Department of Chemistry, An-Najah National University, P. O. Box 7, Nablus, Palestine. ${ }^{2}$ LCAE, Department of Chemistry, Faculty of Sciences, Mohamed Premier University, 60000 Oujda, Morocco. ${ }^{3}$ LCAE, Faculté des Sciences, Université Mohamed I, 60000 Oujda, Morocco. ${ }^{4}$ Division of Plastic and Reconstructive Surgery, Johns Hopkins All Children's Hospital, St. Petersburg, FL, USA.

\section{Received: 19 September 2018 Accepted: 29 June 2019}

\section{Published online: 09 July 2019}

\section{References}

1. Requena M, Parrón T, Navarro A, García J, Ventura MI, Hernández AF, Alarcón R (2018) Association between environmental exposure to pesticides and epilepsy. NeuroToxicology 68:13-18

2. Santos M, Schaule G, Alves A, Madeir LM (2013) Adsorption of paraquat herbicide on deposits from drinking water networks. Chem Eng J. 229:324-333

3. Yarpuz-Bozdogan N (2018) The importance of personal protective equipment in pesticide applications in agriculture. Curr Opin Environ Sci Health 4:1-4

4. Salvia V, Jrad A, Raviglione D, Zhou Y, Bertrand C (2017) Environmental Metabolic Footprinting (EMF) vs. half-life: a new and integrative proxy for the discrimination between control and pesticides exposed sediments in order to further characterise pesticides' environmental impact. Environ Sci Pollut Res 1:1. https://doi.org/10.1007/s1135 6-017-9600-6

5. Shrivas K, Ghosale A, Nirmalkar N, Srivastava A, Singh SK, Shinde S (2017) Removal of endrin and dieldrin isomeric pesticides through stereoselective adsorption behavior on the graphene oxide-magnetic nanoparticles. Environ Sci Pollut Res 24:24980-24988

6. Tan KL, Hameed BH (2017) Insight into the adsorption kinetics models for the removal of contaminants from aqueous solutions. J Taiwan Inst Chem Eng. 74:25-48

7. Aimer Y, Benali O, Serrano KG (2019) Study of the degradation of an organophosphorus pesticide using electrogenerated hydroxyl radicals or heat-activated persulfate. Separ Purif Technol. https://doi. org/10.1016/j.seppur.2018.05.066

8. Rawtani D, Khatri N, Tyagi S, Pandey G (2018) Nanotechnology-based recent approaches for sensing and remediation of pesticides. J Environ Manag 206:749-762

9. Derylo-Marczewska A, Blachnio M, Marczewski AW, Swiatkowski A, Buczek B (2017) Adsorption of chlorophenoxy pesticides on activated carbon with gradually removed external particle layers. Chem Eng J 308:408-418

10. Kumar S, Kaushik G, Dar MA, Nimesh S, Lopez-Chuken UJ, VillarrealChiu JF (2018) Microbial degradation of organophosphate pesticides: a review. Pedosphere 28:190-208

11. Long F, Zhu A, Shi H, Sheng J, Zhao Z (2015) Adsorption kinetics of pesticide in soil assessed by optofluidics-based biosensing platform. Chemosphere 120:615-620

12. Nkansah MA, Donkoh M, Akoto O (2019) Ephraim preliminary studies on the use of sawdust and peanut shell powder as adsorbents for phosphorus removal from water. Emerg Sci J 3:33-40

13. Elhadiri N, Bouchdoug M, Benchanaa M, Boussetta A (2018) Optimization of preparation conditions of novel adsorbent from sugar scum using response surface methodology for removal of methylene blue. Emerg Sci J. 1:1. https://doi.org/10.1155/2018/2093654

14. Arasaretnam T, Kirudchayini A (2019) Studies on synthesis, characterization of modified phenol formaldehyde resin and metal adsorption of modified resin derived from lignin biomass. Emerg Sci J. https://doi. org/10.28991/esj-2019-01173
15. Beidokhti M, Naeeni S, AbdiGhahroudi M (2019) Biosorption of Nickel(II) from aqueous solutions onto Pistachio Hull waste as a lowcost biosorbent. Civil Eng J. 1:1. https://doi.org/10.28991/cej-201903091259

16. Nasiri EF, Kebria DY, Qaderi F (2018) An experimental study on the simultaneous phenol and chromium removal from water using titanium dioxide photocatalyst. Civil Eng J. 1:1. https://doi.org/10.28991/ cej-0309117

17. Otero R, Fernández JM, González MA, Pavlovic I, Ulibarri MA (2013) Pesticides adsorption-desorption on Mg-Al mixed oxides. Kinetic modeling, competing factors and recyclability. Chem Eng J. 2013(221):214-221

18. Wang S, Tu H, Wan J, Chen W, Liu X, Luo J, Xu J, Zhang H (2016) Spatiotemporal distribution and natural variation of metabolites in citrus fruits. Food Chemistry 15:8-17

19. Bapat G, Labade C, Zinjarde S (2016) Silica nanoparticle based techniques for extraction, detection, and degradation of pesticides. Adv Coll Interface Sci. 237:1-14

20. Vojoudi H, Badiei A, Bahar S, Ziarani GM, Faridbod F, Ganjali MR (2017) A new nano-sorbent for fast and efficient removal of heavy metals from aqueous solutions based on modification of magnetic mesoporous silica nanospheres. J Magn Magn Mater 441:193-203

21. Doğan M, Turhan Y, Alkan M, Namli H, Turan P, Demirbaş Ö (2008) Functionalized sepiolite for heavy metal ions adsorption. Desalination 230(1-3):248-268

22. Tighadouini S, Radi S, Bacquet M, Degoutin S, Zaghrioui M, Jodeh S, Warad I (2017) Removal efficiency of Pb(II), Zn (II), Cd (II) and Cu (II) from aqueous solution and natural water by ketoenol-pyrazole receptor functionalized silica hybrid adsorbent. Sep Sci Technol 52(4):608-621

23. Radi S, Tighadouini S, Hadda T, Akkurt M, Özdemir N, Sirajuddin M, Mabkhot YN (2016) Crystal structure of (2Z)-3-hydroxy-1-(1,5-dimethyl1 Hpyrazol-3-yl)but-2-en-1-one. Zeitschrift für Kristallographie. New Crystal Struct. 231:617-618

24. Rai MK, Das JV, Gupta VK (1997) A sensitive determination of paraquat by spectrophotometry. Talanta 45:343-348

25. Tsai WT, Hsien KJ, Chang YM, Lo CC (2005) Removal of herbicide paraquat from an aqueous solution by adsorption onto spent and treated diatomaceous earth. Bioresour Technol 96:657-663

26. Santos MS, Schaule G, Alves A, Madeira LM (2013) Adsorption of paraquat herbicide on deposits from drinking water networks. Chem Eng J. 229:324-333

27. Pateiro-Moure M, Pérez-Novo C, Arias-Estévez M, Rial-Otero R, SimalGándara J (2009) Effect of organic matter and iron oxides on quaternary herbicide sorption-desorption in vineyard-devoted soils. J Colloid Interface Sci. 333:431-438

28. Jodeh S, Hamed O, Melhem A, Salghi R, Jodeh D, Azzaoui K, Benmassaoud Y, Murtada K (2018) Magnetic nanocellulose from olive industry solid waste for the effective removal of methylene blue from wastewater. Environ Sci Poll Res 1:1. https://doi.org/10.1007/s11356-018-2107-y

29. Elyahyaoui A, Ellouzi K, Al Zabadi H, Razzouki B, Bouhlassa S, Azzaoui K, Mejdoubi E, Hamed O, Jodeh S, Lamhamdi A (2017) Adsorption of chromium ( $\mathrm{VI}$ ) on calcium phosphate: mechanisms and stability constants of surface complexes. Appl Sci. 7(3):222-230

30. Lakrata M, Azzaouia K, Jodehb S, Akartassea N, Mejdoubia E, Lamhamdia A, Berrabaha M, Hamedb O, Razzoukid B, Algarrae M (2017) The removal of methyl orange by nanohydroxyapatite from aqueous solution:isotherm, kinetics and thermodynamics studies. Desalin Water Treatm 85:237-249

31. Haghseresht F, Lu G (1998) Adsorption characteristics of phenolic compounds onto coal-reject-derived adsorbents. Energy Fuels 12:1100-1107

32. Fytianos K, Voudrias E, Kokkalis E (2000) Sorption-desorption behavior of 2,4-dichlorophenol by marine sediments. Chemosphere 40:3-6

33. Lagergren SK (1898) About the theory of so-called adsorption of soluble substances. Kungliga Svenska Vetenskapsakademiens. Handlingar 24:1-39

34. Ho YS, McKay G (1999) Pseudo-second-order model for sorption processes. Process Biochem 34:451-465

35. Weber WJ, Morris JC (1963) Kinetics of adsorption on carbon from solution. J Sanit Eng Div Am Soc Civ Eng. 89:31-60 
36. Ahatnagar A, Minocha AK, Jeon BH, Park JM (2007) Adsorptive removal of cobalt from aqueous solutions by utilizing industrial waste and its cement fixation. Sep Sci Technol. 42:1255-1266

37. Salam MA (2013) Coating carbon nanotubes with crystalline manganese dioxide nanoparticles and their application for lead ions removal from model and real water. Colloids Surf A. 419:69-79

\section{Publisher's Note}

Springer Nature remains neutral with regard to jurisdictional claims in published maps and institutional affiliations.
Ready to submit your research? Choose BMC and benefit from:

- fast, convenient online submission

- thorough peer review by experienced researchers in your field

- rapid publication on acceptance

- support for research data, including large and complex data types

- gold Open Access which fosters wider collaboration and increased citations

- maximum visibility for your research: over 100M website views per year

At BMC, research is always in progress.

Learn more biomedcentral.com/submissions 